\title{
Perancangan Sistem Kendali pada Periode Waktu untuk Lansia Menggunakan Sepeda Statis
}

\author{
Nabilah Hanun'), Farida Arinie Soelistianto' ${ }^{2)}$, Rachmad Saptono ${ }^{3)}$ \\ 1, 2, 3 Program Studi Jaringan Telekomunikasi Digital, \\ Jurusan Teknik Elektro, Politeknik Negeri Malang, Indonesia \\ $\underline{{ }^{1} \text { hanunnabilah3@gmail.com, }}$ 라.garida.arinie@polinema.ac.id, $\underline{{ }^{3} \text { rachmad.saptono@polinema.ac.id }}$
}

\begin{abstract}
The average senior spends his time indoors also needs enough exercise, so a static bike is needed that can display heart rate and body temperature data while exercising, so that further action can be taken after knowing the measurement results. On static bikes there are Heart Rate sensors, DS18B20 temperature sensors, and Infrared FC-51 sensors as detectors for the number of laps and wheel speeds. When the elderly start cycling with the selected duration and the photodiode sensor detects the presence of rotation then the Heart Rate sensor and DS18B20 sensor will be able to display heart rate and body temperature data. Data from sensors during cycling is transmitted wirelessly via NodeMCU so that it can be displayed in the android app until the time runs out and the alarm will sound, from the data obtained can result in a normal or abnormal diagnosis of heart rate and body temperature values. In addition, it can also be known the quality of body temperature and heart rate based on the number of rounds and the speed of the wheel. From the results of the study can be concluded that the determination of normal diagnosis in the elderly when the body temperature ranges from $35^{\circ} \mathrm{C}-38^{\circ} \mathrm{C}$ and the heart rate can be calculated by a formula that is 220 minus age. During the process of sending data obtained average - troughput average of 9 tests of $6,153 \mathrm{~Kb} / \mathrm{s}$ with a minimum delay of $28,590 \mathrm{~ms}$ and maximal of $88,078 \mathrm{~ms}$.
\end{abstract}

Keywords - pulse heart sensor, body temperature, FC-51 infrared sensor, android, elderly.

Abstrak - Lansia yang rata - rata menghabiskan waktunya didalam rumah juga membutuhkan olahraga cukup, sehingga dibutuhkan sepeda statis yang dapat menampilkan data detak jantung dan suhu tubuh saat berolahraga, sehingga dapat dilakukan pengambilan tindakan selanjutnya setelah mengetahui hasil pengukuran. Pada sepeda statis sudah terpasang sensor Heart Rate, sensor suhu DS18B20, dan sensor Infrared FC-51 sebagai pendeteksi jumlah putaran dan kecepatan roda. Saat lansia mulai bersepeda dengan durasi yang sudah dipilih dan sensor photodioda mendeteksi adanya putaran maka sensor Heart Rate dan sensor DS18B20 akan dapat menampilkan data detak jantung dan suhu tubuh. Data dari sensor selama bersepeda dikirimkan secara wireless melalui NodeMCU sehingga dapat ditampilkan dalam aplikasi android hingga waktu habis dan alarm akan berbunyi, dari data yang diperoleh dapat dihasilkan diagnosis normal atau tidak normal nilai detak jantung dan suhu tubuh. Selain itu juga dapat diketahui kualitas suhu tubuh dan detak jantung berdasarkan jumlah putaran dan kecepatan roda. Dari hasil penelitian dapat disimpulkan bahwa penentuan diagnosis normal pada lansia saat suhu tubuh berkisar pada $35^{\circ} \mathrm{C}-38^{\circ} \mathrm{C}$ dan detak jantung dapat dihitung dengan rumus yaitu 220 dikurangi usia. Selama proses pengiriman data diperoleh rata - rata troughput dari 9 kali pengujian sebesar 6,153 Kb/s dengan dengan delay minimal sebesar 28,590 ms dan maximal $88,078 \mathrm{~ms}$.

Kata kunci-Sensor detak jatung, suhu tubuh, sensor infrared FC-51, android, lansia.

\section{PENDAHULUAN}

Kesehatan merupakan suatu hal yang mahal dan harus dijaga oleh setiap orang, dengan tubuh yang sehat orang dapat melakukan aktifitas dengan maksimal dan lancar tanpa gangguan [1]. Menjaga kesehatan tubuh manusia dapat dilakukan dengan menjaga pola makan, olahraga, dan istirahat yang cukup. Mengkonsumsi makanan tidak hanya dilihat dari kwantitasnya tetapi juga harus diperhatikan kualitasnya, karena jenis makanan dan jumlah makanan yang dikonsumsi dapat berdampak pada kondisi fisik dan energi yang didapatkan. Disisi lain juga dibutuhkan olahraga, olahraga merupakan kegiatan yang bertujuan untuk memperbaiki dan melatih kinerja fisik seperti kekuatan otot, jantung, pembuluh darah, dan pernapasan [2]. Olahraga ini dibutuhkan bagi semua kalangan mulai dari anak - anak hingga lanjut usia atau lansia.

Menurut WHO lanjut usia dikelompokkan menjadi tiga kelompok, yaitu middle age (45-59 tahun), kelompok elderly age (60-74 tahun), dan kelompok old age (75-90 tahun). Berdasarkan undang - undang Nomor 13 Tahun 1998 tentang Kesejahteraan Lanjut Usia Pada Bab 1 Pasal 1 Ayat 2, menurut undang undang tersebut lanjut usia adalah seseorang yang mencapai usia 60 tahun ke atas, baik pria maupun wanita. Klasifikasi lansia berdasarkan usia yaitu pralansia (usia 45 - 59 tahun), lansia (usia 60 tahun atau lebih), dan lansia resiko tinggi (70 tahun atau lebih / seseorang berusia 60 tahun lebih dengan masalah kesehatan) [3]. Lansia akan mengalami kemunduran fungsi - fungsi dalam tubuh yang dapat menimbulkan berbagai akibat jika tidak ditangani dengan baik dan akan mempengaruhi kesehatan lansia secara menyeluruh. Faktor yang dapat digunakan untuk menjaga kesehatan dan kebugaran lansia yaitu dengan berolahraga. Lansia dianjurkan untuk melakukan aktivitas fisik selama sekitar 30 menit setiap hari. Olahraga yang disarankan untuk lansia adalah olahraga yang bersifat aerobik (tidak terlalu membebani tulang) seperti berjalan, bersepeda statis, senam lansia, berenang, dan lain lain. Olahraga aerobik adalah olahraga yang membuat jantung dan paru - paru bekerja lebih keras untuk memenuhi kebutuhan oksigen yang meningkat. Manfaat olahraga bagi lansia antara lain dapat memperpanjang usia, menyehatkan jantung, otot, 
dan tulang, membuat lansia lebih mandiri, mencegah obesitas, dan mengurangi kecemasan dan depresi [1].

Kondisi fisik dan sistem organ yang mengalami penurunan pada lansia membutuhkan pemantauan seperti pemeriksaan dasar fungsi tubuh atau tanda vital. Pemeriksaan tanda vital merupakan pengukuran fungsi tubuh yang paling dasar untuk mengetahui tanda klinis dan berguna untuk memperkuat diagnosis suatu penyakit, parameter vital sign yang sangat mendasar dalam menentukan kondisi fisik seseorang yaitu detak jantung dan suhu tubuh. Denyut Jantung adalah jumlah ketukan dalam satu menit, rata-rata kecepatan detak jantung menunjukkan aktifitas jantung. Jumlah denyut jantung tidak dapat diatur manusia karena jantung bekerja secara refleks, terutama saat berolahraga. Perubahan suhu tubuh juga dapat mengindikasikan sesuatu dalam tubuh manusia seperti jika terjadi infeksi, radang, dan lain - lain. Suhu tubuh adalah perbedaan antar jumlah panas yang diproduksi oleh proses tubuh dan jumlah panas yang hilang ke lingkungan luar. Perubahan suhu tubuh sangat erat kaitannya dengan produksi panas maksimal maupun pengeluaran panas yang berlebihan. Sifat perubahan panas tersebut sangat mempengaruhi masalah klinis yang dialami setiap orang [4]. Suhu tubuh dapat dipengaruhi oleh faktor usia, aktivitas, lingkungan, dan peradangan.

Kebutuhan berolahraga yang cukup sangat penting bagi lansia, akan tetapi kebanyakan lansia mengahabiskan waktunya beraktifitas didalam rumah, di sisi lain juga dibutuhkan pemantauan kondisi tubuh. Maka dibutuhkan suatu alat olahraga bagi lansia berupa sepeda statis yang termasuk dalam olahraga ringan dan sudah disertai dengan alat pengukur tanda vital seperti detak jantung dan suhu tubuh. Cukup dengan di rumah, lansia dapat melakukan olahraga kapanpun sesuai dengan kemauan dan dapat mengetahui kondisi vital saat berolahraga. Dasar inilah yang kemudian timbul gagasan untuk membuat "Perancangan Sistem Kendali Pada Waktu Untuk Lansia Menggunakan Sepeda Statis", dengan adanya alat ini diharapkan dapat membantu memudahkan lansia dalam melakukan olahraga dan dapat mengetahui jumlah detak jantung dan suhu tubuh berdasarkan perputaran roda sepeda selama berolahraga. Sehingga, dapat dilakukan pengambilan tindakan selanjutnya setelah mengetahui hasil pengukuran.

\section{METODE}

Penelitian ini dilakukan di Politeknik Negeri Malang Program Studi Jaringan Telekomunikasi Digital pada Juli 2020 yang digunakan untuk mengetahui permasalahan yang sedang dilakukan, yaitu tentang peran pemanfaatan sensor suhu dan detak jantung pada sepeda statis. Peran tersebut antara lain deteksi keluaran dari sensor suhu dan detak jantung berdasarkan mekanisme perputaran roda sepeda statis, sehingga penelitian ini termasuk dalam research and development yaitu membangun suatu sistem yang diaplikasikan pada alat-alat kesehatan.

\section{A. Tahapan Penelitian}

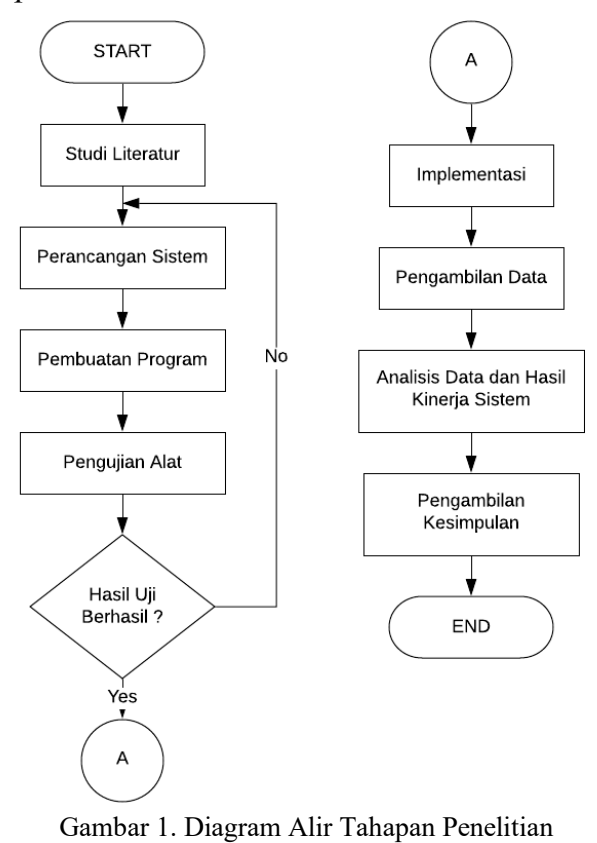

\section{B. Blok Diagram Perangkat}

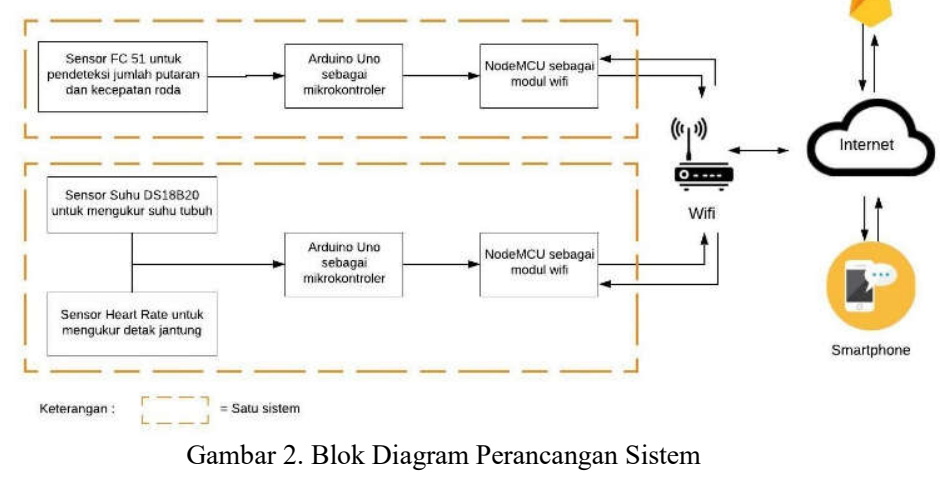

Pada gambar 2 menunjukkan blok diagram perancangan sistem, berikut ini penjelasannya:

\section{1) Sensor Infrared FC-51}

Sensor Infrared FC-51 berfungsi sebagai pembaca nilai kecepatan roda sepeda dan jumlah putaran saat bersepeda, data yang didapatkan akan diolah pada arduino uno sebagai salah satu parameter untuk pengaturan perputaran roda sepeda.

\section{2) Sensor Suhu}

Sensor suhu DS18B20 berfungsi sebagai pembaca nilai suhu tubuh pengguna sepeda statis yang mana datanya akan diolah di arduino uno sebagai salah satu parameter untuk monitoring suhu.

\section{3) Sensor Detak Jantung}

Sensor detak jantung atau Heart rate pulse sensor berfungsi sebagai pembaca nilai detak jantung saat bersepeda, yang mana data yang didapatkan akan diolah pada arduino uno sebagai salah satu parameter detak jantung. 


\section{4) Arduino Uno}

Arduino uno berfungsi sebagai mikrokontroler yang digunakan untuk mengontrol kerja sensor sesuai dengan program yang sudah ditentukan.

\section{5) NodeMCU}

NodeMCU berfungsi sebagai perangkat transmisi data hasil dari pengolahan arduino uno yang dilakukan secara wireless dengan mengunakan Wifi antara perangkat sistem dengan android menggunakan bantuan firebase sebagai database atau penyimpanan data oleh sensor.

\section{6) Android}

Android berperan sebagai perangkat yang digunakan untuk menampilkan data dalam bentuk text maupun grafik yang telah diolah dari blok input dan blok proses.

\section{Diagram Sistem Keseluruhan}

Pada gambar 3 saat perangkat sudah terkoneksi dengan jaringan Wifi dan pengguna sudah mulai mengayuh sepeda, sensor photodioda mulai bekerja mengambil data banyaknya putaran dan kecepatan roda. Jika terdeteksi adanya putaran pada roda maka sensor Heart Rate dan sensor suhu DS18B20 mulai mengambil data yang langsung dikirimkan kepada server firebase dan selanjutnya akan ditampilkan pada aplikasi android.

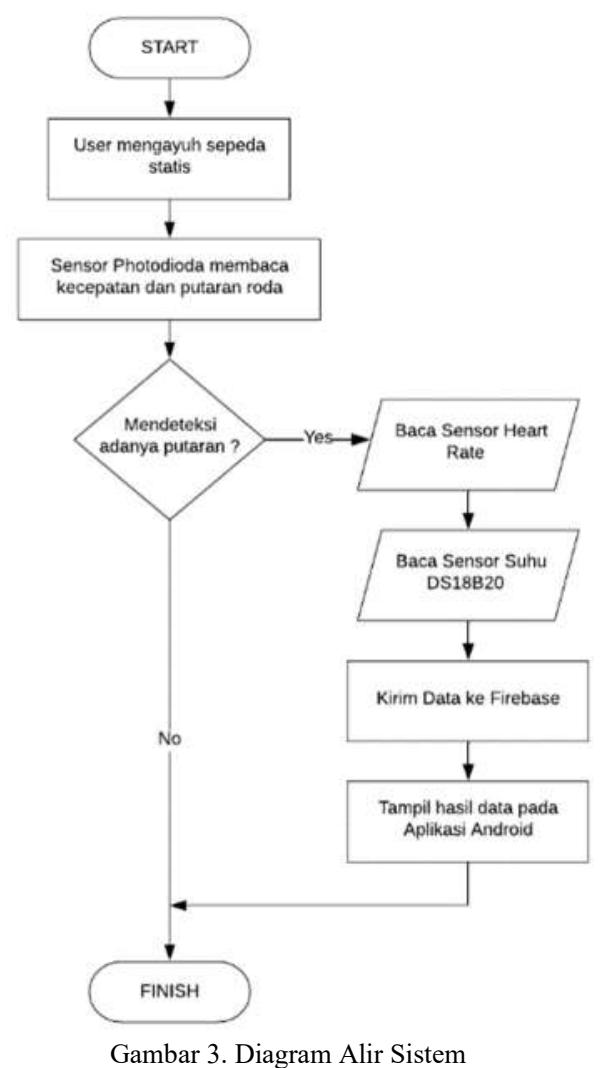

\section{Diagram Alir Aplikasi Android}

Pada gambar 4 menjelaskan tentang flowchart aplikasi android, pertama-tama user yang akan melakukan olahraga memilih opsi lama waktu bersepeda sesuai dengan keinginan mulai dari 5 menit sampai dengan 30 menit. Kemudian klik tombol mulai untuk memulai waktu olahraga yang secara otomatis data detak jantung, suhu tubuh, putaran roda, dan kecepatan roda yang didapatkan oleh sensor ditampilkan pada aplikasi. Perhitungan waktu olahraga sama seperti stopwatch sehingga jika waktu olahraga sudah habis maka alarm pada android pengguna akan berbunyi. Setelah alarm berbunyi, pengguna bisa menekan tombol "Aktivasi Data Olahraga" yang akan menampil data pengukuran selama berolahraga dan agar memperoleh diagnosis normal atau tidaknya detak jantung serta suhu tubuh pengguna saat berolahraga. Batasan diagnosis normal pada suhu tubuh antara $35^{\circ} \mathrm{C}-38^{\circ} \mathrm{C}$, sedangkan diagnosis normal detak jantung menggunakan perhitungan dengan persamaan (2) diatas. Pengguna juga dapat membagikan notifikasi kondisi pengguna selama berolahraga kepada orang terdekat yang sudah tercantum dalam aplikasi.

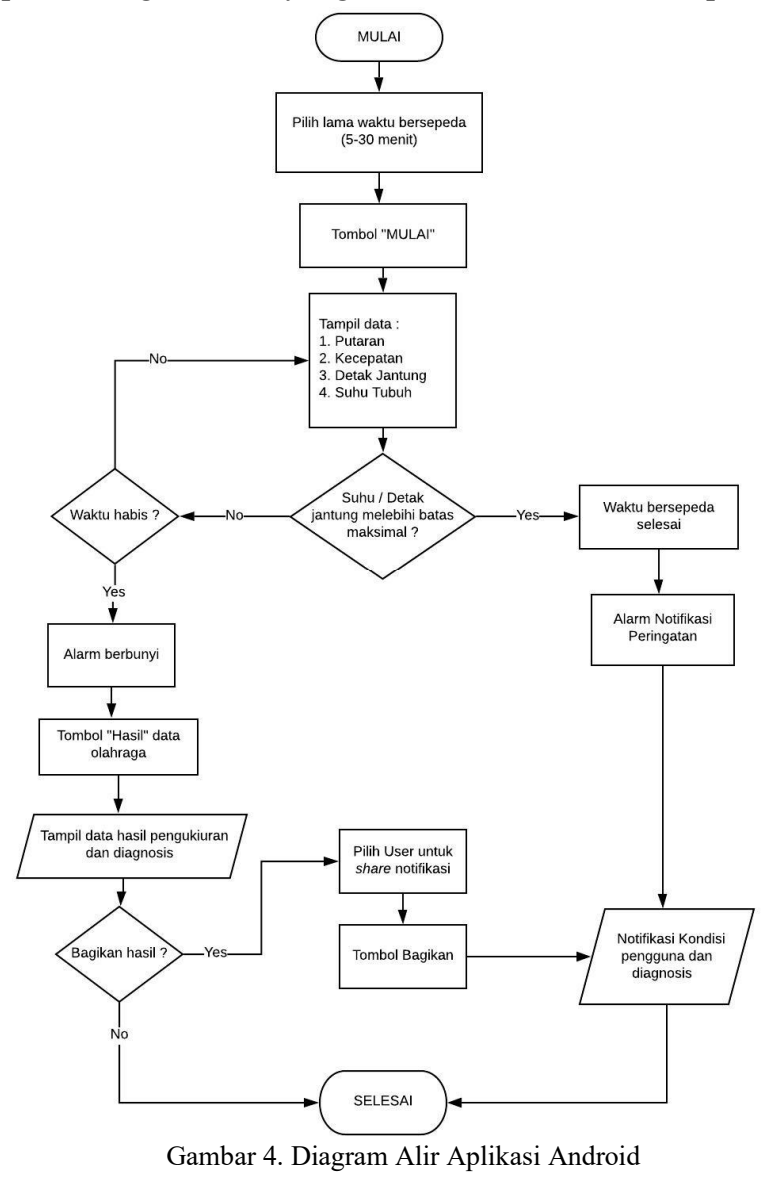

\section{E. Uji Coba Alat}

Tahapan uji coba ini meliputi pengujian sistem penelitian dengan alat agar mengetahui bahwa sistem sudah berjalan sesuai dengan perencanaan

TABEL I

HASIL KALIBRASI SENSOR SUHU

\begin{tabular}{lllll}
\hline $\begin{array}{l}\text { Pengujian } \\
\text { User ke - }\end{array}$ & Durasi & $\begin{array}{l}\text { Sensor } \\
\text { Suhu } \\
\text { DS18B20 }\end{array}$ & Termometer & $\begin{array}{l}\text { Deviasi } \\
\text { Error } \\
\text { (\%) }\end{array}$ \\
\hline 1 & 1 menit & $35,50{ }^{\circ} \mathrm{C}$ & $35,6^{\circ} \mathrm{C}$ & 0,28 \\
& 2 menit & $35,75{ }^{\circ} \mathrm{C}$ & $35,9^{\circ} \mathrm{C}$ & 0,41 \\
\hline
\end{tabular}


Jurnal Jaringan Telekomunikasi E-ISSN: 2654-6531 P-ISSN: 2407-0807 Vol. 11, No.2 (2021) 101-106

\begin{tabular}{|c|c|c|c|c|c|}
\hline \multicolumn{2}{|c|}{$\begin{array}{l}\text { Pengujian } \\
\text { User ke - }\end{array}$} & \multirow{2}{*}{\begin{tabular}{|l} 
Durasi \\
3 menit
\end{tabular}} & \multirow{2}{*}{$\begin{array}{l}\begin{array}{l}\text { Sensor } \\
\text { Suhu } \\
\text { DS18B20 }\end{array} \\
35,93{ }^{\circ} \mathrm{C}\end{array}$} & \multirow{2}{*}{$\begin{array}{l}\text { Termometer } \\
36^{\circ} \mathrm{C}\end{array}$} & \multirow{2}{*}{$\begin{array}{l}\begin{array}{l}\text { Deviasi } \\
\text { Error } \\
(\%)\end{array} \\
0,19\end{array}$} \\
\hline & & & & & \\
\hline & & 4 menit & $36,20^{\circ} \mathrm{C}$ & $36,4^{\circ} \mathrm{C}$ & 0,54 \\
\hline & & 5 menit & $36,44^{\circ} \mathrm{C}$ & $36,5^{\circ} \mathrm{C}$ & 0,16 \\
\hline \multirow{5}{*}{\multicolumn{2}{|c|}{2}} & 1 menit & $36,38^{\circ} \mathrm{C}$ & $36,2^{\circ} \mathrm{C}$ & 0,49 \\
\hline & & 2 menit & $36,4^{\circ} \mathrm{C}$ & $36,5^{\circ} \mathrm{C}$ & 0,27 \\
\hline & & 3 menit & $36,67^{\circ} \mathrm{C}$ & $36,6^{\circ} \mathrm{C}$ & 0,19 \\
\hline & & 4 menit & $36,8^{\circ} \mathrm{C}$ & $36,7^{\circ} \mathrm{C}$ & 0,27 \\
\hline & & 5 menit & $36,90^{\circ} \mathrm{C}$ & $36,7^{\circ} \mathrm{C}$ & 0,54 \\
\hline \multirow{5}{*}{\multicolumn{2}{|c|}{3}} & 1 menit & $35,5^{\circ} \mathrm{C}$ & $35,6^{\circ} \mathrm{C}$ & 0,28 \\
\hline & & 2 menit & $35,8^{\circ} \mathrm{C}$ & $35,6^{\circ} \mathrm{C}$ & 0,55 \\
\hline & & 3 menit & $36^{\circ} \mathrm{C}$ & $35,9^{\circ} \mathrm{C}$ & 0,27 \\
\hline & & 4 menit & $35,94^{\circ} \mathrm{C}$ & $36^{\circ} \mathrm{C}$ & 0,16 \\
\hline & & 5 menit & $36,06^{\circ} \mathrm{C}$ & $36,2^{\circ} \mathrm{C}$ & 0,38 \\
\hline \multirow{5}{*}{\multicolumn{2}{|c|}{4}} & 1 menit & $36,12^{\circ} \mathrm{C}$ & $36^{\circ} \mathrm{C}$ & 0,33 \\
\hline & & 2 menit & $36,26^{\circ} \mathrm{C}$ & $36,1^{\circ} \mathrm{C}$ & 0,16 \\
\hline & & 3 menit & $36,26^{\circ} \mathrm{C}$ & $36,2^{\circ} \mathrm{C}$ & 0,16 \\
\hline & & 4 menit & $36,3^{\circ} \mathrm{C}$ & $36,2^{\circ} \mathrm{C}$ & 0,27 \\
\hline & & 5 menit & $36,38^{\circ} \mathrm{C}$ & $36,3^{\circ} \mathrm{C}$ & 0,22 \\
\hline \multirow[t]{6}{*}{5} & & 1 menit & $35,98^{\circ} \mathrm{C}$ & $36,2^{\circ} \mathrm{C}$ & 0,6 \\
\hline & & 2 menit & $36,2^{\circ} \mathrm{C}$ & $36,3^{\circ} \mathrm{C}$ & 0,27 \\
\hline & & 3 menit & $36,22^{\circ} \mathrm{C}$ & $36,3^{\circ} \mathrm{C}$ & 0,22 \\
\hline & & 4 menit & $36,48^{\circ} \mathrm{C}$ & $36,4^{\circ} \mathrm{C}$ & 0,21 \\
\hline & & 5 menit & $36,56^{\circ} \mathrm{C}$ & $36,3^{\circ} \mathrm{C}$ & 0,7 \\
\hline & \multicolumn{5}{|c|}{ TABEL II } \\
\hline $\begin{array}{l}\text { User } \\
\text { Ke-. }\end{array}$ & Usia & $\begin{array}{l}\text { Jam } \\
\text { Pelaksa }\end{array}$ & Dur & $\begin{array}{l}\text { Jumlah } \\
\text { Putaran }\end{array}$ & Suhu \\
\hline 1 & 20 & 07.45 & $5 \mathrm{mc}$ & 1.311 & $36,44^{\circ} \mathrm{C}$ \\
\hline 2 & 21 & 08.00 & $5 \mathrm{~m}$ & 989 & $36,90^{\circ} \mathrm{C}$ \\
\hline 3 & 20 & 08.20 & $5 \mathrm{~m}$ & 1.442 & $36,06^{\circ} \mathrm{C}$ \\
\hline 4 & 22 & 09.35 & $5 \mathrm{mc}$ & 1.120 & $36,38^{\circ} \mathrm{C}$ \\
\hline 5 & 50 & 10.10 & $5 \mathrm{~ms}$ & 666 & $36,56^{\circ} \mathrm{C}$ \\
\hline
\end{tabular}

Berdasarkan tabel II menunjukkan bahwa jumlah putaran pada kualitas suhu tubuh setiap orang berbeda-beda.

F. Pengujian Kalibrasi dan Keakurasian Sensor Detak Jantung

TABEL III

HASIL KALIBRASI SENSOR DETAK JANTUNG

\begin{tabular}{lllll}
\hline $\begin{array}{l}\text { Pengujian } \\
\text { User ke- }\end{array}$ & Durasi & $\begin{array}{l}\text { Sensor } \\
\text { Detak } \\
\text { Jantung }\end{array}$ & Oximeter & $\begin{array}{l}\text { Deviasi } \\
\text { Error } \\
\text { (\%) }\end{array}$ \\
\hline 1. & 1 menit & $97 \mathrm{bpm}$ & $97 \mathrm{bpm}$ & 0 \\
& 2 menit & $101 \mathrm{bpm}$ & $100 \mathrm{bpm}$ & 1 \\
& 3 menit & $103 \mathrm{bpm}$ & $104 \mathrm{bpm}$ & 0,96 \\
& 4 menit & $110 \mathrm{bpm}$ & $111 \mathrm{bpm}$ & 0,9 \\
2. & 5 menit & $111 \mathrm{bpm}$ & $112 \mathrm{bpm}$ & 0,89 \\
& 1 menit & $85 \mathrm{bpm}$ & $85 \mathrm{bpm}$ & 0 \\
& 2 menit & $84 \mathrm{bpm}$ & $85 \mathrm{bpm}$ & 1,17 \\
& 3 menit & $90 \mathrm{bpm}$ & $91 \mathrm{bpm}$ & 1,09 \\
3. & 4 menit & $97 \mathrm{bpm}$ & $98 \mathrm{bpm}$ & 1,02 \\
& 5 menit & $106 \mathrm{bpm}$ & $107 \mathrm{bpm}$ & 0,93 \\
& 1 menit & $102 \mathrm{bpm}$ & $103 \mathrm{bpm}$ & 0,97 \\
& 2 menit & $95 \mathrm{bpm}$ & $94 \mathrm{bpm}$ & 1,06 \\
& 3 menit & $98 \mathrm{bpm}$ & $98 \mathrm{bpm}$ & 0 \\
4. & 4 menit & $89 \mathrm{bpm}$ & $90 \mathrm{bpm}$ & 1,11 \\
& 5 menit & $85 \mathrm{bpm}$ & $85 \mathrm{bpm}$ & 0 \\
& 1 menit & $90 \mathrm{bpm}$ & $91 \mathrm{bpm}$ & 1,09 \\
& 2 menit & $87 \mathrm{bpm}$ & $88 \mathrm{bpm}$ & 1,13 \\
& 3 menit & $98 \mathrm{bpm}$ & $98 \mathrm{bpm}$ & 0 \\
& 4 menit & $115 \mathrm{bpm}$ & $115 \mathrm{bpm}$ & 0 \\
& 5 menit & $95 \mathrm{bpm}$ & $96 \mathrm{bpm}$ & 1,04 \\
& 1 menit & $100 \mathrm{bpm}$ & $101 \mathrm{bpm}$ & 0,99 \\
& 2 menit & $90 \mathrm{bpm}$ & $90 \mathrm{bpm}$ & 0 \\
\hline & & & & \\
& & & & \\
& & & &
\end{tabular}

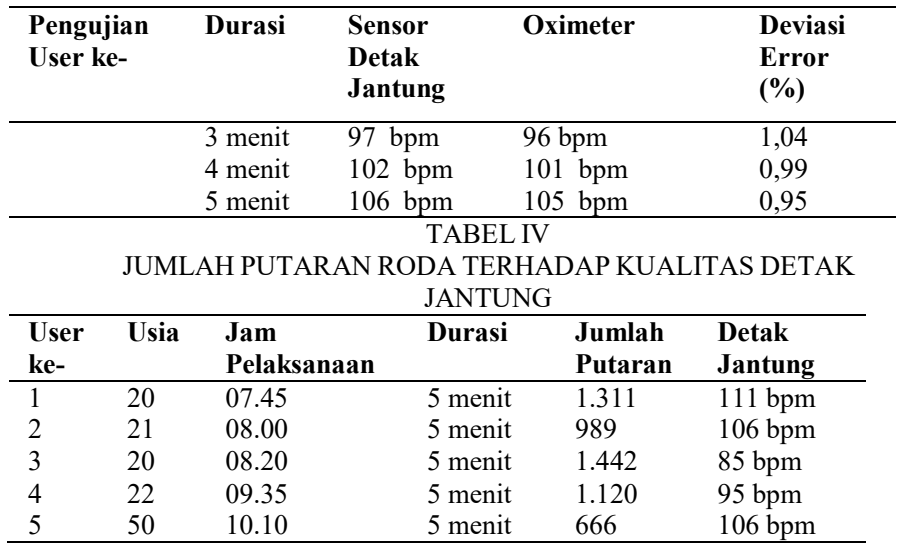

Berdasarkan table IV menunjukkan bahwa jumlah putaran pada kualitas jumlah detak jantung setiap orang berbeda-beda.

\section{HASIL DAN PEMBAHASAN}

Hasil pengujian keseluruhan dari sistem yang telah dibuat dan pembahasan mengenai analisis hasil pengujian. Adapun tujuan dari pengujian ini untuk mengetahui bahwa sistem yang telah dirancang dapat bekerja dan berfungsi dengan baik sesuai dengan perencanaan.

\section{A. Hasil Penelitian}

TABEL IV

HASIL PENGAMBILAN DATA PADA SEPEDA STATIS TANPA BEBAN

\begin{tabular}{|c|c|c|c|c|c|c|c|c|}
\hline $\begin{array}{l}\mathbf{N} \\
\mathbf{0}\end{array}$ & Nama & $\begin{array}{l}\text { Usia } \\
\text { (Ta } \\
\text { hun } \\
\text { ) }\end{array}$ & $\begin{array}{l}\text { Dura } \\
\text { si } \\
\text { (Men } \\
\text { it) }\end{array}$ & $\begin{array}{l}\text { Suh } \\
\text { u } \\
\left({ }^{\circ} \mathrm{C}\right. \\
)\end{array}$ & $\begin{array}{l}\text { Deta } \\
\text { k } \\
\text { Jant } \\
\text { ung } \\
\text { (bpm } \\
\text { ) }\end{array}$ & $\begin{array}{l}\text { Kece } \\
\text { patan } \\
\text { (RP } \\
\text { M) }\end{array}$ & $\begin{array}{l}\text { Juml } \\
\text { ah } \\
\text { Puta } \\
\text { ran }\end{array}$ & $\begin{array}{l}\text { Dia } \\
\text { gn } \\
\text { osi } \\
\text { s }\end{array}$ \\
\hline \multirow[t]{5}{*}{1.} & \multirow[t]{5}{*}{ Tati } & \multirow[t]{5}{*}{78} & 1 & $\begin{array}{l}35 \\
45\end{array}$ & 102 & 141 & 212 & \multirow{5}{*}{$\begin{array}{l}\text { Tid } \\
\text { ak } \\
\text { No } \\
\text { rm } \\
\text { al }\end{array}$} \\
\hline & & & 2 & $\begin{array}{l}35 \\
51\end{array}$ & 126 & 141 & 404 & \\
\hline & & & 3 & $\begin{array}{l}35 \\
56\end{array}$ & 135 & 134 & 559 & \\
\hline & & & 4 & $\begin{array}{l}35 \\
50\end{array}$ & 143 & 122 & 741 & \\
\hline & & & 5 & $\begin{array}{l}35 \\
56\end{array}$ & 152 & 127 & 929 & \\
\hline \multirow[t]{5}{*}{2.} & \multirow[t]{5}{*}{ Suyati } & \multirow[t]{5}{*}{72} & 1 & $\begin{array}{l}35 \\
5\end{array}$ & 98 & 104 & 168 & \multirow{5}{*}{$\begin{array}{l}\text { No } \\
\mathrm{rm} \\
\text { al }\end{array}$} \\
\hline & & & 2 & $\begin{array}{l}35 \\
47\end{array}$ & 124 & 96 & 271 & \\
\hline & & & 3 & $\begin{array}{l}35 \\
44\end{array}$ & 89 & 3750 & 459 & \\
\hline & & & 4 & $\begin{array}{l}35 \\
44\end{array}$ & 89 & 107 & 563 & \\
\hline & & & 5 & $\begin{array}{l}35 \\
4\end{array}$ & 89 & 93 & 747 & \\
\hline \multirow[t]{3}{*}{3.} & \multirow[t]{3}{*}{$\begin{array}{l}\text { Hartat } \\
\text { i }\end{array}$} & 74 & 1 & $\begin{array}{l}35 \\
38\end{array}$ & 89 & 150 & 197 & \multirow{3}{*}{$\begin{array}{l}\text { No } \\
\text { rm } \\
\text { al }\end{array}$} \\
\hline & & & 2 & $\begin{array}{l}35 \\
4\end{array}$ & 102 & 147 & 302 & \\
\hline & & & 3 & $\begin{array}{l}35 \\
4\end{array}$ & 84 & 93 & 551 & \\
\hline
\end{tabular}


Jurnal Jaringan Telekomunikasi E-ISSN: 2654-6531 P-ISSN: 2407-0807 Vol. 11, No.2 (2021) 101-106

\begin{tabular}{|c|c|c|c|c|c|c|c|c|}
\hline $\begin{array}{l}\mathbf{N} \\
\mathbf{0}\end{array}$ & Nama & $\begin{array}{l}\text { Usia } \\
\text { (Ta } \\
\text { hun } \\
\text { ) }\end{array}$ & $\begin{array}{l}\text { Dura } \\
\text { si } \\
\text { (Men } \\
\text { it) }\end{array}$ & $\begin{array}{l}\text { Suh } \\
\text { u } \\
\left({ }^{\circ} \mathrm{C}\right. \\
)\end{array}$ & $\begin{array}{l}\text { Deta } \\
\text { k } \\
\text { Jant } \\
\text { ung } \\
\text { (bpm } \\
\text { ) }\end{array}$ & $\begin{array}{l}\text { Kece } \\
\text { patan } \\
\text { (RP } \\
\text { M) }\end{array}$ & $\begin{array}{l}\text { Juml } \\
\text { ah } \\
\text { Puta } \\
\text { ran }\end{array}$ & $\begin{array}{l}\text { Dia } \\
\text { gn } \\
\text { osi } \\
\text { s }\end{array}$ \\
\hline & & & 4 & $\begin{array}{l}35, \\
42\end{array}$ & 94 & 112 & 645 & \\
\hline & & & 5 & $\begin{array}{l}35, \\
6\end{array}$ & 94 & 131 & 824 & \\
\hline \multirow[t]{5}{*}{4.} & $\begin{array}{l}\text { Yaumi } \\
1\end{array}$ & 22 & 1 & $\begin{array}{l}36, \\
56\end{array}$ & 101 & 123 & 100 & $\begin{array}{l}\text { No } \\
\text { rm }\end{array}$ \\
\hline & & & 2 & $\begin{array}{l}36, \\
5\end{array}$ & 107 & 141 & 358 & al \\
\hline & & & 3 & $\begin{array}{l}36, \\
69\end{array}$ & 106 & 135 & 556 & \\
\hline & & & 4 & $\begin{array}{l}36, \\
70\end{array}$ & 119 & 129 & 786 & \\
\hline & & & 5 & $\begin{array}{l}36, \\
8\end{array}$ & 121 & 250 & $\begin{array}{l}1.33 \\
5\end{array}$ & \\
\hline \multirow[t]{5}{*}{5.} & Kholif & 22 & 1 & $\begin{array}{l}36, \\
3\end{array}$ & 84 & 130 & 121 & $\begin{array}{l}\text { No } \\
\mathrm{rm}\end{array}$ \\
\hline & & & 2 & $\begin{array}{l}36, \\
44\end{array}$ & 115 & 145 & 240 & al \\
\hline & & & 3 & $\begin{array}{l}36, \\
56\end{array}$ & 108 & 235 & 561 & \\
\hline & & & 4 & $\begin{array}{l}36, \\
6\end{array}$ & 105 & 260 & 620 & \\
\hline & & & 5 & $\begin{array}{l}36 \\
6\end{array}$ & 109 & 363 & 998 & \\
\hline \multirow[t]{5}{*}{6.} & Rizky & 21 & 1 & $\begin{array}{l}36, \\
45\end{array}$ & 89 & 139 & 242 & $\begin{array}{l}\text { No } \\
\text { rm }\end{array}$ \\
\hline & & & 2 & $\begin{array}{l}36 \\
48\end{array}$ & 96 & 250 & 451 & al \\
\hline & & & 3 & $\begin{array}{l}36, \\
55\end{array}$ & 99 & 250 & 634 & \\
\hline & & & 4 & $\begin{array}{l}36, \\
60\end{array}$ & 110 & 278 & 922 & \\
\hline & & & 5 & $\begin{array}{l}36, \\
63\end{array}$ & 117 & 331 & $\begin{array}{l}1.30 \\
7\end{array}$ & \\
\hline
\end{tabular}

- Dari hasil pengambilan data pada table IV menunjukkan bahwa pengguna saat menggunakan sepeda statis dengan beban diperoleh nilai suhu tubuh dan detak jantung mencapai $37^{\circ} \mathrm{C}$ dan $140 \mathrm{bpm}$ yang masih dalam kategori diagnosis normal.

\section{B. Hasil Pengujian Pengiriman Data}

Hasil pengujian pengiriman data dari hasil sensor atau Quality of Service (QoS) yang digunakan untuk mengetahui kualitas pengiriman data pada saat sensor mengirimkan data kepada server sehingga dapat ditampilkan pada aplikasi android. Pengujian QoS ini menggunakan 3 parameter pengukuran yaitu delay, packet loss, dan troughput dengan bantuan softwere Wireshark.

\section{1) Troughput}

Troughput dapat dihitung dengan menggunakan rumus dibawah ini.

$$
\text { Troughput }=\frac{\text { Bytes }}{\text { time } \operatorname{span}} \times 8
$$

$$
\begin{aligned}
& \quad=\frac{27850}{12,161} \times 8 \\
& =18320,8618 \mathrm{~b} / \mathrm{s} \\
& =18,320 \mathrm{~Kb} / \mathrm{s}
\end{aligned}
$$

\section{Statistics}

\begin{tabular}{|lll|}
\multicolumn{1}{l}{ Measurement } & Captured & Displayed \\
\hline Packets & 248 & $248(100.0 \%)$ \\
\hline Time span, s & 12.161 & 12.16 \\
\hline Average pps & 20.4 & 20.4 \\
Average packet size, B & 112 & 112 \\
\hline Bytes & 27850 & $27850(100.0 \%)$ \\
\hline Average Dytes/s & 2290 & 2290 \\
Average bits/s & $18 \mathrm{k}$ & $18 \mathrm{k}$ \\
& Gambar 5. Troughput & \\
\hline
\end{tabular}

\section{2) Packet Loss}

\section{Statistics}

\begin{tabular}{lll}
\hline Measurement & Captured & Displayed \\
\hline Packets & 248 & $248(100.0 \%)$ \\
\hline IIme span, s & 12.161 & 12.161 \\
Average pps & 20.4 & 20.4 \\
Average packet size, B & 112 & 112 \\
Bytes & 27850 & $27850(100.0 \%)$ \\
Average bytes $/ \mathrm{s}$ & 2290 & 2290 \\
Average bits/s & $18 \mathrm{k}$ & $18 \mathrm{k}$
\end{tabular}

$$
\begin{aligned}
\text { Packet Loss }=\frac{\begin{array}{c}
\text { Gambar } 6 . \text { Jumlah Paket yang Diterima } \\
\text { Pakirim }- \text { paket data diterima })
\end{array}}{\text { Paket dikirim }} \times 100 \% \\
=\frac{(248-248)}{248} \times 100 \% \\
=0 \%
\end{aligned}
$$

\begin{tabular}{|c|c|c|c|c|}
\hline No. & Jumlah Paket & $\begin{array}{l}\begin{array}{l}\text { Delay } \\
\text { (ms) }\end{array} \\
\text { (m) }\end{array}$ & $\begin{array}{l}\text { Troughput } \\
(\mathrm{Kb} / \mathrm{s})\end{array}$ & $\begin{array}{l}\text { Packet } \\
\text { Loss (\%) }\end{array}$ \\
\hline & Request $=4$ Bytes & & 18,320 & 0 \\
\hline \multirow[t]{2}{*}{1} & Reply $=4$ Bytes & 38,519 & & \\
\hline & Request $=5$ Bytes & & 6,310 & 0 \\
\hline \multirow[t]{2}{*}{2} & Reply $=5$ Bytes & 44,512 & & \\
\hline & Request $=6$ Bytes & & 2,160 & 0 \\
\hline \multirow[t]{2}{*}{3} & Reply $=6$ Bytes & 88.078 & & \\
\hline & Request $=7$ Bytes & & 1,533 & 0 \\
\hline \multirow[t]{2}{*}{4} & Reply $=7$ Bytes & 34,197 & & \\
\hline & Request $=8$ Bytes & & 19,577 & 0 \\
\hline \multirow[t]{2}{*}{5} & Reply $=8$ Bytes & 28,590 & & \\
\hline & Request $=9$ Bytes & & 1,322 & 0 \\
\hline \multirow[t]{2}{*}{6} & Reply $=9$ Bytes & 62,039 & & \\
\hline & Request $=10$ Bytes & & 1,205 & 0 \\
\hline \multirow[t]{2}{*}{7} & Reply $=10$ Bytes & 28,931 & & \\
\hline & Request $=11$ Bytes & & 1,765 & 0 \\
\hline \multirow[t]{2}{*}{8} & Reply $=11$ Bytes & 34,666 & & \\
\hline & Request $=12$ Bytes & & 3,187 & 0 \\
\hline 9 & Reply $=12$ Bytes & 53,889 & & \\
\hline Rata-rata & & & $6,153 \mathrm{~Kb} / \mathrm{s}$ & \\
\hline
\end{tabular}

3) Delay

TABEL V HASIL PENGUKURAN DELAY

\section{KESIMPULAN}

Sensor suhu dan detak jantung digunakan sebagai indikator dari pemanfaatan sepeda statis pada lansia dengan usia 65 
tahun keatas berdasarkan kecepatan dan jumlah perputaran roda.

Penentuan diagnosis normal pada suhu tubuh yaitu $35^{\circ} \mathrm{C}$ $38^{\circ} \mathrm{C}$ saat berolahraga sedangkan batas maksimal normal detak jantung dapat dihitung dengan maksimal jumlah detak jantung yaitu 220 dikurangi usia, jika nilai suhu tubuh dan detak jantung kurang dari atau lebih dari batas normal maka termasuk dalam diagnosis tidak normal.

Selama proses pengiriman data dari setiap sensor diperoleh rata - rata throughput sebesar $6,153 \mathrm{~Kb} / \mathrm{s}$

\section{REFERENSI}

[1] D. K. P, "Menjaga Kesehatan Di Usia Lanjut," Jorpres, vol. 11, no. 2, pp. 19-30, 2015.

[2] I. N. Sand, "Sumber Dan Metabolisme Energi Dalam Olahraga," J. Chem. Inf. Model., vol. 53, no. 9, pp. 16891699, 2013.

[3] D. N. Chasanah, "Pemantauan Kesehatan Pada Lanjut Usia Berbasis Mikrokontroler," vol. 02, no. 01, pp. 123128, 2018.

[4] I. Prayogo, R. Alfita, and K. A. Wibisono, "Sistem Monitoring Denyut Jantung Dan Suhu Tubuh Sebagai Indikator Level Kesehatan Pasien Berbasis Iot (Internet Of Thing) Dengan Metode Fuzzy Logic Menggunakan Android," J. Tek. Elektro dan Komput. TRIAC, vol. 4, no. 2, 2017.

[5] T. S. Sollu, A. Alamsyah, M. Bachtiar, A. Amir, and B. Bontong, "Sistem Monitoring Detak Jantung dan Suhu Tubuh Menggunakan Arduino," Techno.Com, vol. 17, no. 3, pp. 323-332, 2018.

[6] A. Sholeh, A. I. Juniani, and Y. N. Devi, "Analisis dan Perancangan Sepeda Statis untuk Rehabilitasi Penderita Stroke," pp. 11-16, 2015.

[7] A. Suwandi, E. Maulana, and F. D. Rhapsody, "ERGONOMIS," vol. III, no. 2, pp. 24-31, 2017.

[8] R. F. Tias and M. M. Hidayat, "Analisis dan Desain SiBIOS: Deteksi Dini Kondisi Jantung dan Peningkatan Kualitas Hidup Manusia," Techno.Com, vol. 17, no. 3, pp. 312-322, 2018.

[9] L. Hermawan, H. Setyo, and S. Rahayu, "Pengaruh Pemberian Asupan Cairan (Air) Terhadap Profil Denyut Jantung Pada Aktivitas Aerobik," JSSF (Journal Sport Sci. Fitness), vol. 1, no. 2, pp. 14-20, 2012.

[10]A. Pribadi, "PELATIHAN AEROBIK UNTUK KEBUGARAN PARU JANTUNG BAGI LANSIA," $J$. Olahraga Prestasi, 2015.

[11] B. N. Balmain, S. Sabapathy, M. Louis, and N. R. Morris, "Aging and Thermoregulatory Control: The Clinical Implications of Exercising under Heat Stress in Older Individuals," vol. 2018. 